\title{
Pendampingan Emosi dan Kemampuan Mengelola Emosi pada Karyawan yang Mengalami Perubahan Organisasi
}

\section{Emotional Coaching and the Emotional Management Ability on Organizational Members that Get into Organizational Change}

\author{
Nur Afni Indahari Arifin \\ Fakultas Psikologi Universitas Negeri Makassar, Makasar 90222 \\ Rasimin B. Sanmustari \\ Fakultas Psikologi Universitas Gadjah Mada, Yogyakarta 55281 \\ Diterima 19 Oktober 2009/Disetujui 5 November 2009
}

\begin{abstract}
Organizational change causes various reactions toward organizational members, include emotional reaction. The aim of this research is to improve the emotional management ability on organizational members that get into organizational change through emotional coaching method. Participants in this research were three employees that get organizational change. The experiment design used Small $n$ Experiment with ABA design. Research participants followed the designed meeting schedule for a month. The intervention effectiveness measured by Resistance to Change Scale (Oreg, 2003). The results showed that emotional coaching significantly able to improve employee emotional management ability toward organizational change.
\end{abstract}

Keywords: emotional coaching, emotional management, organizational change

Perubahan organisasi merupakan sebuah proses pergerakan dari kondisi saat ini menuju kondisi di masa depan yang diharapkan dapat meningkatkan efektivitas organisasi (Jones, 2004). Untuk itu organisasi dituntut agar menyesuaikan strategi bisnisnya dengan berbagai bentuk perubahan lingkungan, baik lingkungan eksternal maupun internal organisasi (Himam, 2005).

Kreitner dan Kinicki (2003) menjelaskan bahwa pada dasarnya terdapat dua jenis kekuatan yang mendorong adanya perubahan dalam organisasi, yaitu kekuatan yang bersumber dari lingkungan eksternal dan internal organisasi. Kekuatan eksternal

\footnotetext{
- Penulis Korespondensi :

HP: 081392702770; Email: afni_arifin@yahoo.co.id.
} 
menimbulkan dampak yang bersifat global, sehingga menjadi acuan bagi organisasi dalam menentukan jenis bisnis atau produk dan pelayanan yang akan diberikan. Kekuatan ini bersumber dari karakteristik demografi, perkembangan teknologi, perubahan pasar, dan tekanan sosial politik. Kekuatan ini menimbulkan dampak yang bersifat menyeluruh, sehingga menjadi acuan bagi organisasi dalam menentukan jenis bisnis atau produk dan pelayanan yang akan diberikan. Adapun kekuatan internal bersumber dari masalah-masalah sumber daya manusia dan perilaku, serta keputusan manajerial. Misalnya adalah rendahnya kepuasan kerja, produktivitas, atau timbulnya berbagai macam konflik.

Hasil penelitian Weber dan Weber (2001) menunjukkan bahwa pada umumnya perubahan organisasi dapat menimbulkan dampak serius pada sikap dan produktivitas karyawan. Karyawan dapat bersikap skeptis bahkan menolak, baik secara aktif maupun pasif untuk berubah sehingga tujuan organisasi menjadi terhambat.

Mirip dengan penelitian tersebut, Smitter, Houston, dan McIntire (1996) mengemukakan bahwa apabila perubahan dianggap sebagai sebuah ancaman, maka akan terjadi penolakan terhadap proses perubahan. Hal tersebut dapat disebabkan beberapa faktor berikut: (1) Perubahan tidak dianggap sebagai sesuatu yang diperlukan; (2) Terdapat kesalahpahaman mengenai tujuan, proses, dan hasil dari perubahan; (3) Rasa takut anggota organisasi terkait dengan perubahan, termasuk adalah kondisi yang serba tidak pasti, sehingga muncul perilaku seperti menolak dipromosikan karena menghindari pekerjaan baru dengan tugas dan tanggungjawabnya; ataupun muncul kesan yang buruk terhadap teman dan rekan kerja; (4) Rasa tidak aman dari segi ekonomi dan takut kehilangan status; (5) Adanya ancaman dalam interaksi sosial karena perubahan dapat berupa penataan ulang dari kelompok kerja dalam suatu organisasi; (6) Keengganan meninggalkan rutinitas kerja dan kebiasaan lama.

Perubahan organisasi dapat mempengaruhi emosi karyawan. Meskipun fokus utamanya pada rasionalisasi dan efisiensi, namun proses perubahan hampir selalu menunjukkan isu penting yang membangkitkan emosi seperti takut akan kegagalan, penolakan, cemas, dan marah (Cummings dan Worley, 2005).

Emosi didefinisikan sebagai gejolak dan perasaan yang kuat. Emosi merupakan suatu peralihan dari situasi normal yang dialami oleh organisme berupa adanya perasaan yang kuat, impuls untuk berperilaku, dan reaksi fisik tertentu, ditandai dengan timbulnya perasaan takut, marah, muak, sedih, senang, heran, dan rindu. Emosi dipandang sebagai faktor dinamis yang melatarbelakangi tindakan dan bukan hanya sekedar keadaan dalam diri seseorang (Kupers, 2001). 
Ketidaksadaran

Kesadaran

$\vec{\Gamma}$ Emosi dan kebutuhan

Stimulus $\rightarrow$ Perhatian $\rightarrow$ Skema Emosi $\rightarrow$ Tendensi untuk bertindak $\rightarrow$ Perilaku Pikiran

Gambar 1. Rangkaian Proses Emosi

Sumber: Greenberg (2002)

Berdasarkan gambar 1 terlihat bahwa emosi adalah faktor yang melatarbelakangi perilaku dan bukan sekedar keadaan dalam diri seseorang. Hadirnya stimulus secara tidak disadari mengaktifkan skema emosi. Hal ini kemudian menyebabkan perubahan ke level kesadaran di mana emosi dan kebutuhan, pikiran, serta tendensi untuk bertindak saling berinteraksi dan mempengaruhi yang kemudian melahirkan perilaku.

Strongman (2003) mengemukakan bahwa emosi adalah sesuatu yang sifatnya subjektif. Subjektivitas dari emosi dapat menjadi kekuatan yang sangat besar dan berperan dalam menentukan perilaku seseorang. Secara sadar, emosi akan dimanifestasikan dalam bentuk pengalaman emosi yang akan membentuk persepsi seseorang dalam memandang sesuatu. Emosi pada awalnya akan mengevaluasi apakah sesuatu itu baik atau buruk bagi seseorang dan memberikan predisposisi tindakan yang mengekspresikan keinginan atau kebutuhan (Greenberg, 2002).

Menurut Plutchik (Lupton, 1998), emosi adalah rangkaian kompleks dari reaksi atas stimulus; meliputi penilaian kognitif, perubahan subjektif, otonomi, bangkitnya syaraf, keinginan untuk bertindak, dan perilaku yang didesain sebagai efek dari stimulus melalui rangkaian yang kompleks. Pendekatan kognitif menyatakan bahwa manusia membuat penilaian dalam hubungannya dengan sensasi fisik yang dirasakan ketika memutuskan keadaan emosional apa yang sedang dialaminya. Berdasarkan pengertian-pengertian tersebut, emosi yang dimaksud dalam penelitian ini adalah perasaan yang dimiliki oleh seseorang sebagai respon atas sesuatu, yang kemudian dievaluasi secara kognitif dan selanjutnya menjadi tekanan untuk berperilaku. Emosi dalam penelitian ini lebih ditekankan pada emosi-emosi negatif.

Gross (Strongman, 2003) mengemukakan lima proses dalam regulasi emosi: (1) Pemilihan situasi. Seseorang dapat mendekati atau menghindari orang lain, tempat, atau objek lainnya; (2) Modifikasi situasi. Hal ini berhubungan dengan koping yang difokuskan pada 
masalah; (3) Penyebaran perhatian. Contohnya adalah mengalihkan, berkonsentrasi, dan atau merenungkan; (4) Perubahan kognitif. Secara umum merupakan transformasi kognitif untuk mengubah pengaruh emosional yang kuat atas sebuah situasi; (5) Modifikasi respon. Dapat dilakukan dengan menggunakan obat-obatan, alkohol, latihan, terapi, makanan, atau menekan perasaan. Hal ini merupakan bentuk regulasi emosi yang dipikirkan oleh kebanyakan orang.

Hasil penelitian yang dilakukan oleh Gross (Manz, 2007) juga menunjukkan bahwa menahan reaksi-reaksi emosi kurang efektif untuk meringankan pengalaman emosional yang negatif dibandingkan jika seseorang menerapkan strategi-strategi mengetahui dan mengatur emosi (seperti menilai kembali situasi yang sulit). Selain itu, menahan reaksi atas emosi juga cenderung merusak memori.

Proses perubahan organisasi hampir selalu menunjukkan isu penting yang membangkitkan emosi. Penelitian yang dilakukan oleh Kiefer (2005) menunjukkan bahwa ketika perubahan berlangsung dalam suatu organisasi, maka akan menimbulkan pengalaman emosi bagi individu yang terlibat di dalamnya. Secara khusus, perubahan organisasi cenderung diasosiasikan dengan emosi negatif yang dapat mengakibatkan timbulnya persepsi tentang masa depan yang tidak aman, serta persepsi tentang fasilitas organisasi yang tidak cukup. Smitter, Houston, dan McIntire (1996) mengemukakan bahwa ketidakpastian akibat adanya perubahan dalam organisasi akan menimbulkan perasaan asing bagi anggota organisasi. Hal tersebut menyebabkan kecemasan dan ketakutan.

Perubahan organisasi merupakan salah satu faktor yang dapat menimbulkan krisis pekerjaan bagi karyawan. Hasil penelitian yang dilakukan oleh Hutri dan Lindeman (2002) menunjukkan bahwa perubahan organisasi mengakibatkan timbulnya stres dan emosi negatif yang diwujudkan dalam bentuk kecemasan, marah, dan simtom-simtom depresi. Oleh karena itu, berdasarkan hasil penelitian Huy dan Insead (1999) dapat diketahui kecerdasan emosi dapat memfasilitasi individu dalam beradaptasi terhadap perubahan. Kecerdasan emosi menggabungkan kemampuan lebih luas yang menjelaskan cara individu mengelola emosi. Kecerdasan emosi menjadi variabel moderator antara reaksi emosional karyawan pada rasa tidak aman dalam pekerjaannya dan kemampuannya untuk beradaptasi dengan stres (Jordan, Ashkanasy, dan Hartel, 2002).

Salah satu contoh perubahan organisasi adalah restrukturisasi di tubuh PT. Bosowa Group yang kemudian berubah menjadi Bosowa Corporation. Perubahan terjadi untuk merespon persaingan usaha yang semakin ketat. Semua anak perusahaan yang terdiri atas empat grup bisnis digabung ke dalam satu corporation. Imbasnya adalah sejumlah anak 
perusahaan, jabatan-jabatan, maupun prosedur kerja yang dinilai tidak efisien dihilangkan optimalisasi dan efisiensi diterapkan di setiap unit kerja (Bosowa Excellence Magazine, 2007).

Lebih jauh, Nur (2007) mengungkapkan bahwa perubahan organisasi tersebu menimbulkan berbagai pengalaman emosi, baik yang bersifat positif seperti senang dan bangga, maupun yang negatif seperti kecewa, jengkel, dan dilema. Pengalaman emosi dapat menjadi sumber motivasi atau sumber ketegangan bagi karyawan. Pada saat terdapat sejumlah kondisi yang dianggap masih menguntungkan bagi karyawan, maka karyawan cenderung memiliki semangat dalam melaksanakan aktivitas kerja di tengah ketidakpastian yang ditimbulkan oleh perubahan organisasi yang berlangsung. Namun, bagi karyawan yang merasa tidak ada lagi yang dapat diharapkan dari perubahan organisasi tersebut, maka karyawan cenderung untuk bekerja apa adanya, sekedar sebagai rutinitas atau sebagai syarat yang harus dipenuhi agar dapat tetap bekerja pada perusahaan tersebut.

Menindaklanjuti hasil penelitian Nur (2007) tersebut, maka peneliti ingin melakukan studi lanjutan pada organisasi tersebut. Hasilnya menunjukkan bahwa $57,14 \%$ dari 35 orang karyawan yang diteliti di salah satu cabang perusahaan masih mengalami penyesuaian secara emosional dengan perubahan. Reaksi emosional karyawan tersebut tergolong sedang, artinya masih merasakan emosi-emosi negatif terkait dengan perubahan. Akibatnya karyawan bekerja dengan standar minimal. Sikap ini menunjukkan adanya resistensi terhadap perubahan. Menurut Kreitner dan Kinicki (2003), resistensi terhadap perubahan adalah respon emosional/perilaku terhadap perubahan kerja yang nyata atau yang dibayangkan akan mengancam rutinitas kerja yang telah dibuat. Resistensi terhadap perubahan dalam garis kontinum terdiri atas penerimaan, tak terbedakan/apatis, resistensi pasif, dan resistensi aktif. Adanya perilaku karyawan yang menunjukkan resistensi tersebut menunjukkan perlunya intervensi untuk meningkatkan kemampuan pengelolaan emosi dalam menghadapi perubahan. Salah satunya adalah melalui pelatihan emosi.

Gross (Greenberg, 2002) menyebutkan agar seseorang mampu berperilaku dengan kecerdasan emosional, maka perlu pengelolaan pengalaman emosi dan ekspresi emosinya. Hasil penelitian yang dilakukan oleh Cote dan Morgan (2002) juga menunjukkan bahwa menekan emosi yang tidak menyenangkan akan menurunkan kepuasan kerja, yang kemudian meningkatkan keinginan untuk keluar dari pekerjaan. Selain itu, penguatan terhadap emosi-emosi yang menyenangkan akan meningkatkan kepuasan kerja.

Menurut Mayer dan Salovey (1997), individu yang memiliki pengelolaan emosi yang baik akan dapat mengenal dan memahami emosi diri sendiri serta orang lain. Selain itu, orang yang mampu mengelola emosi juga dapat mengetahui dan menerapkan bagaimana cara 
mengatasi dan mengontrol emosi, serta mengetahui strategi apa yang harus digunakan dalam menghadapi emosi orang lain. Mengelola emosi yang dimaksud dalam penelitian ini adalah kemampuan karyawan untuk menyesuaikan diri secara emosional dengan perubahan, sehingga karyawan mampu menerima perubahan organisasi yang dialami dan menganggap perubahan sebagai hal yang biasa terjadi. Berdasarkan langkah-langkah pendampingan emosi (emotional coaching) yang dikemukakan oleh Greenberg (2002), karyawan dikatakan telah memiliki kemampuan pengelolaan emosi jika mampu menerima dan menyesuaikan diri dengan perubahan, memiliki alternatif-alternatif pemecahan masalah, serta mempunyai tujuan baru yang lebih maju.

Penelitian ini bertujuan untuk meningkatkan kemampuan mengelola emosi pada karyawan yang mengalami perubahan organisasi melalui pendampingan (coaching). Menurut Cummings dan Worley (2005), coaching merupakan intervensi yang didesain untuk meningkatkan kompetensi individual anggota organisasi melalui dukungan, umpan balik, dan visi yang baru terhadap pekerjaan serta organisasi, juga cara-cara baru dalam berhubungan dengan orang-orang. Coaching secara khusus ditujukan untuk satu atau lebih dari tujuan berikut: membantu manajer agar dapat melakukan beberapa perubahan secara lebih efektif, seperti penggabungan organisasi atau pengurangan tenaga kerja; untuk mengatasi masalah kinerja; atau mengembangkan beberapa keterampilan perilaku sebagai bagian dari program pengembangan kepemimpinan. Coaching pada dasarnya adalah membantu orang-orang mengembangkan potensinya dengan memberikan kesempatan untuk mengenali kemampuan dan membantunya menemukan berbagai jalan yang ada di sekitarnya (Somers, 2007).

Pendampingan emosi (emotional coaching) adalah intervensi yang didasarkan pada delapan langkah utama bagaimana membantu emosi seseorang bekerja dalam kehidupan sehari-hari, dalam hal ini membantu seseorang dalam menghadapi perubahan organisasi tempatnya bekerja (Greenberg, 2002). Ada dua tahap dalam emotional coaching, yaitu: (1) Tahap merasakan emosi, yaitu coaching untuk kesadaran terhadap emosi; (2) Tahap menghilangkan emosi, yaitu membantu klien untuk memutuskan apakah klien dapat mempercayai perasaan yang telah diterimanya sebagai sumber informasi yang berguna atau apakah perasaan itu tidak bermanfaat dan perlu diubah.

Berdasarkan penjelasan di atas, maka dapat digambarkan dinamika psikologis sebagai berikut: 


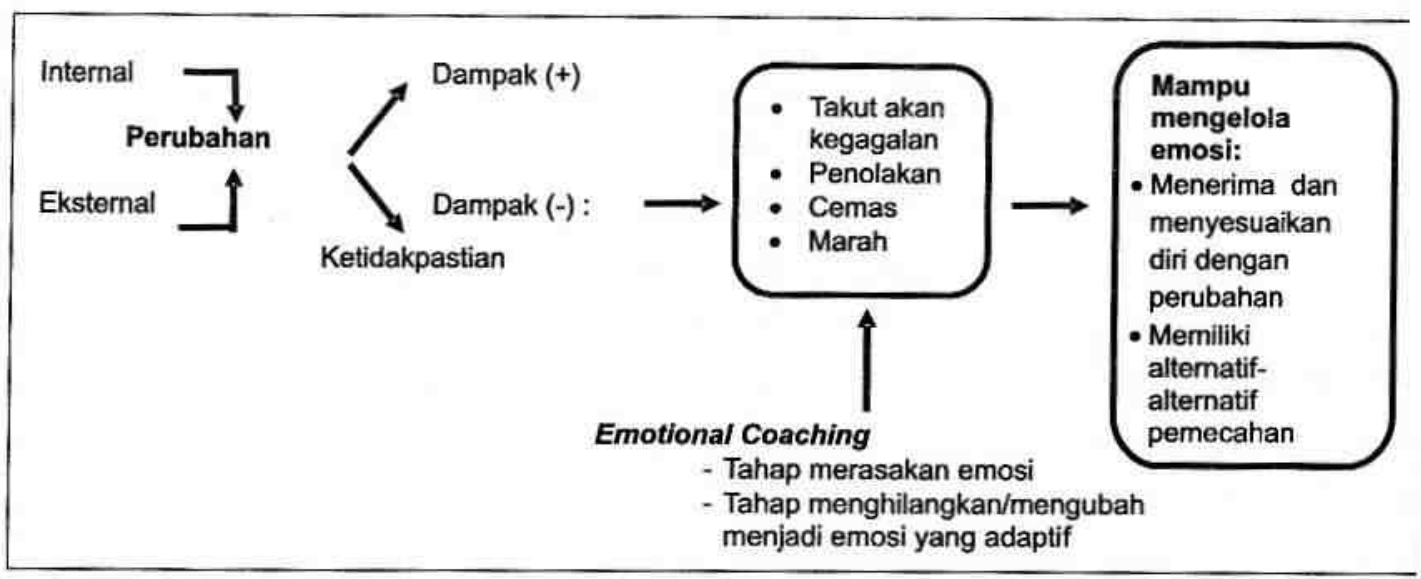

Gambar 2. Dinamika Psikologis

Gambar 2 menunjukkan bahwa faktor internal dan eksternal dari organisasi yang melatarbelakangi lahirnya perubahan. Perubahan kemudian menimbulkan dampak positif dan negatif. Dampak negatif, berupa ketidakpastian, akan memunculkan emosi-emosi negatif seperti takut akan kegagalan, penolakan, cemas, dan marah. Individu yang merasakan emosi-emosi negatif kemudian diberikan pendampingan emosi (emotional coaching), yang meliputi dua tahap yaitu merasakan emosi dan mengubahnya menjadi emosi yang adaptif. Setelah diberikan coaching maka individu diharapkan memiliki kemampuan mengelola emosi. Intervensi ini diharapkan mampu mengubah kognitisi individu mengenai perubahan. Menurut Gross (Strongman, 2003), hal ini sampai pada perubahan kognitif dalam proses mengelola emosi. Indikatornya adalah individu telah menerima dan menyesuaikan diri dengan perubahan, memiliki alternatif-alternatif pemecahan masalah, serta mempunyai tujuan baru yang lebih maju. Berdasarkan hal tersebut maka hipotesis penelitian ini adalah pendampingan emosi (emotional coaching) mampu meningkatkan kemampuan mengelola emosi karyawan dalam menghadapi perubahan organisasi.

\section{Metode Penelitian}

\section{Subjek Penelitian}

Penelitian ini dilakukan pada perusahaan yang mengalami restrukturisasi. Komponennya adalah karyawan yang posisinya terkena secara langsung perubahan dan pengembangan organisasi yang terjadi, serta telah bekerja minimal dua tahun di perusahaan tersebut. Subjek berjumlah tiga orang.

Penentuan subjek dilakukan dengan memberikan Skala Resistensi terhadap Perubahan (sekaligus sebagai prates). Subjek ditentukan berdasarkan skor yang diperoleh (berada dalam kategori sedang, skornya 11-17), serta melalui hasil diskusi dengan pihak manajemen perusahaan. 


\section{Desain Penelitian}

Penelitian ini menggunakan rancangan small sample experiment, desain ABA. Desain $A B A$ merupakan desain eksperimental yang terdiri dari pengulangan pengukuran perilaku partisipan dalam tiga fase, yaitu fase $A$ merupakan fase pengukuran sebelum perlakuan dan fase $B$ merupakan fase pengulangan pengukuran pada saat diberikan perlakuan, serta kembali fase Amerupakan fase pengukuran setelah perlakuan (Barlow \& Hersen, 1984). Pada penelitian ini desain $A B A$ dilakukan sebagai berikut: (1) Fase sebelum coaching (A), dalam fase ini diukur tingkat resistensi terhadap perubahan dan reaksi emosional yang dialami subjek sebelum coaching (pretes); (2) Fase selama menjalani perlakuan (B), dalam fase ini diberikan perlakuan berupa emotional coaching dan diukur tingkat resistensi terhadap perubahan serta reaksi emosional yang dialami subjek setiap minggu untuk melihat kondisinya pada saat menjalani coaching; (3) Fase setelah mengikuti perlakuan (A), dalam fase ini akan diukur tingkat resistensi terhadap perubahan dan reaksi emosional ketika subjek sudah tidakmenjalani coaching, yaitu sebulan setelah berakhirnya proses coaching.

\section{Pengukuran Data}

Pengukuran terhadap keadaan awal subjek dan efektivitas intervensi akan dilakukan melalui Skala Resistensi terhadap Perubahan yang disusun oleh Oreg (2003). Butir dalam skala diterjemahkan sendiri oleh peneliti. Skala terdiri atas 17 butir, dengan pilihan jawaban antara 1 (sangat tidak setuju) sampai 6 (sangat setuju). Skala Resistensi terhadap Perubahan terdiri atas empat subskala, yaitu Subskala Kebiasaan sehari-hari, butir no 1-5; Subskala Reaksi Emosional, butir no. 6-9; Subskala Fokus Jangka Pendek, butir no. 10-13; dan Subskala Kekakuan Berpikir, butir no. 14-17. Total koefisien reliabilitas skala (dengan Alpha Cronbach) adalah 0.92. Koefisien reliabilitas skala untuk Subskala Kebiasaan Sehari-hari, adalah 0.89; Subskala Reaksi Emosional $=0.86$; Subskala Fokus Jangka Pendek $=0.71$; dan Subskala Kekakuan Berpikir $=0.68$.

Pengukuran resistensi terhadap perubahan dilakukan sebelum Emotional Coaching diberikan. Pengukuran selanjutnya diberikan setiap minggu selama subjek menjalani proses coaching. Pengukuran dilanjutkan dengan tindak lanjut sebulan setelah pertemuan coaching berakhir.

Panduan wawancara digunakan peneliti untuk mengetahui apa yang dirasakan subjek pada saat menjalani coaching, mengetahui perubahan yang terjadi, serta apa yang diharapkan pada pertemuan coaching berikutnya. Wawancara sebagai evaluasi terhadap proses dilakukan peneliti setiap selesai pertemuan coaching. Wawancara juga dilakukan 
kepada fasilitator mengenai perkembangan subjek setiap selesai menjalani coaching.

\section{Intervensi}

Setiap subjek menjalani proses pendampingan (emotional coaching) secare individual selama satu bulan. Emotional coaching akan diberikan oleh fasilitator. Syarat fasilitator adalah berprofesi sebagai psikolog, bersedia untuk memberikan coaching selama waktu yang ditetapkan, serta memiliki pengalaman dalam bidang industri dan organisasi. Fasilitator membantu subjek untuk mempersiapkan diri secara emosional dalam menjalani perubahan organisasi. Subjek diminta untuk menceritakan apa yang dirasakan mengenai perubahan yang sedang dialami terhadap dirinya dan organisasi. Coaching ini diberikan untuk meningkatkan kemampuan mengelola emosi subjek sehingga mampu menjalani perubahan organisasi.

Proses penelitian berlangsung dua bulan. Pada tahap awal, subjek dipilih berdasarkan skor yang diperoleh pada Skala Resistensi terhadap Perubahan. Pemberian skala untuk pemilihan subjek juga sekaligus dijadikan pengukuran awal kondisi subjek (pretes). Subjek menjalani coaching selama sebulan. Pertemuan individual dalam rangka pendampingan (emotional coaching) dilakukan sekali seminggu, masing-masing selama dua jam (Yeyentimalla, 2007; Muzdalifah, 2007). Pengukuran lanjutan dilakukan sebulan setelah pertemuan coaching berakhir.

\section{ProsedurPenelitian}

1. Persiapan Penelitian

Persiapan penelitian merupakan tahap awal sebelum peneliti melakukan penelitian. Persiapan penelitian meliputi beberapa hal berikut:

a. Proses penyusunan alat ukur dan modul emotional coaching

Peneliti terlebih dahulu mempelajari emosi, perubahan organisasi, dan emotional coaching sebagai salah satu upaya yang dapat digunakan untuk mempersiapkan individu dalam menjalani perubahan organisasi. Peneliti kemudian menyusun panduan emotional coaching dalam bentuk modul emotional coaching berdasarkan referensi yang telah dipelajari oleh peneliti dan di dalamnya memuat langkah-langkah dalam setiap pertemuan coaching. Pada proses penyusunan juga dilakukan role play untuk memperbaiki instruksi dan bahasa yang digunakan dalam panduan emotional coaching.

Peneliti juga menerjemahkan Skala Resistensi terhadap Perubahan yang 
dibuat oleh Oreg (2003). Uji coba dilakukan pada karyawan yang juga mengalami perubahan organisasi.

b. Proses pemilihan dan pembekalan fasilitator

Emotional coaching dilakukan oleh fasilitator dengan syarat sebagai berikut: berprofesi sebagai psikolog, bersedia untuk memberikan coaching selama waktu yang ditetapkan, dan memiliki pengalaman dalam bidang industri dan organisasi.

Berdasarkan syarat tersebut, maka peneliti memilih dua orang fasilitator yang juga berprofesi sebagai dosen psikologi. Fasilitator yang dipilih kemudian diberikan pengarahan mengenai materi emotional coaching, perubahan organisasi yang terjadi pada lokasi dimana subjek bekerja, serta sekilas mengenai latar belakang subjek penelitian.

c. Pemilihan subjek penelitian

Subjek penelitian dipilih dengan melihat skor yang diperoleh pada skala resistensi terhadap perubahan. Subjek yang dipilih berada dalam kategori sedang, skornya 11-17, serta melalui hasil diskusi dengan pihak manajemen perusahaan. Pertimbangan dalam penentuan subjek adalah bahwa karyawan tersebut mengalami masalah penyesuaian secara emosional dalam menghadapi perubahan organisasi, yaitu masih merasakan emosi-emosi negatif terkait dengan perubahan organisasi yang dialami. Subjek yang berada dalam kategori sedang, dalam hal reaksi emosional terhadap perubahan, berjumlah 19 orang karyawan. Namun karena keterbatasan, yaitu lokasi kerja beberapa karyawan tersebut cukup jauh (berada di luar kota) dan hanya terdapat dua orang yang bersedia menjadi fasilitator maka akhirnya hanya dipilih tiga orang subjek yang diketahui masih mengalami penyesuaian emosional terhadap perubahan organisasi.

2. Pelaksanaan Penelitian

Pelaksanaan emotional coaching dilakukan selama sebulan mulai tanggal 03-29 November 2008. Pertemuan dilaksanakan sekali seminggu, pada hari Jumat atau Sabtu, selama sekitar dua jam. Jadwal pelaksanaan penelitian dapat dilihat pada Tabel 1. 
Tabel 1.

Jadwal Pelaksanaan Penelitian

Pengukuran awal untuk pemilihan subjek ( Jumat, 10 Okt 2008)

Pengukuran awal sebelum intervensi (Senin, 03 Nov 2008)

- Dilakukan kepada semua subjek

Pertemuan I (120 menit)

Jumat, 07 Nov $2008 \rightarrow$ Subjek M.S

Sabtu, 08 Nov $2008 \rightarrow$ Subjek Z dan B.R

Sesi 1: Perkenalan (30 menit)

- Perkenalan antara fasilitator dan klien.

- Penjelasan mengenai maksud dan tujuan coaching.

- Kontrak belajar.

Sesi 2: Kesadaran Emosi (45 menit)

Sesi 3: Penerimaan Pengalaman Emosi (45 menit)

Pertemuan II (120 menit)

Jumat, 14 Nov 2008 Subjek M.S

Sabtu, 15 Nov 2008 Subjek Z dan B.R

- Pengukuran I

- Sesi 1: Menguraikan emosi dengan kata-kata (60 menit)

- Sesi 2: Mengidentifikasi pengalaman klien yang utama (60 menit)

Pertemuan III (120 menit)

Jumat, 21 Nov 2008 Subjek M.S

Sabtu, 22 Nov 2008 Subjek Z dan B.R

- Pengukuran II

- Sesi 1: Mengevaluasi perasaan utama/inti yang dirasakan (60 menit)

- Sesi 2: Mengidentifikasi Kepercayaan destruktif yang ada pada emosi maladaptif (60 menit)

Pertemuan IV (120 menit)

Jumat, 28 Nov $2008 \rightarrow$ Subjek M.S

Sabtu. 29 Nov $2008 \rightarrow$ Subjek Z dan B.R

- Pengukuran III

- Sesi 1: Memfasilitasi masuknya alternatif emosi dan kebutuhan yang adaptif (60 menit)

- Sesi 2: Memfasilitasi perubahan emosi yang maladaptif dan kepercayaan yang destruktif (60 menit)

Pengukuran IV (6 Des 2008) $\rightarrow$ Semua subjek

Pengukuran follow up (29 Des 2008) $\rightarrow$ Semua subjek 
Analisis Data

Analisis terhadap data yang diperoleh dilakukan secara kuantitatif dan dilengkapi dengan analisis wawancara.

1. Analisis data secara kuantitatif dilakukan dengan menggunakan teknik visual inspection (Barlow \& Hersen, 1984). Langkahnya adalah dengan menampilkan dalam grafik skor resistensi terhadap perubahan serta reaksi emosional tahap sebelum, tahap setiap minggu selama proses coaching berlangsung, dan tahap setelah menjalani coaching untuk masing-masing subjek. Data yang diperoleh dalam grafik visual inspection akan dievaluasi dengan melihat bagaimana dinamika skor resistensi terhadap perubahan dan reaksi emosional untuk masing-masing subjek.

2. Analisis data wawancara diperoleh melalui hasil rekaman proses selama coaching berlangsung. Selain itu termasuk data yang diperoleh melalui wawancara terhadap subjek dan fasilitator. Wawancara dilakukan kepada subjek untuk mengetahui apa yang dialami selama proses coaching diberikan dan perubahan apa yang telah dirasakannya setelah menjalani proses intervensi. Wawancara dengan fasilitator dilakukan untuk mengetahui perkembangan subjek setiap minggu selama proses coaching berlangsung. Wawancara dilakukan setiap selesai menjalani pertemuan Pendampingan Emosi (Emotional Coaching).

\section{Hasil Penelitian}

Hasil penelitian menunjukkan bahwa pendampingan emosi (emotional coaching) mampu meningkatkan kemampuan mengelola emosi karyawan dalam menjalani perubahan organisasi.

Selama menjalani proses coaching, masing-masing subjek merasakan perubahan yang lebih positif. Hal ini dapai diketahui dari adanya perubahan respon subjek terhadap program yang diberikan. Pada awalnya, subjek merasa berat untuk menjalani coaching. Namun, setelah membaca Informed Consent disertai dengan penjelasan mengenai pentingnya program ini, maka subjek bersedia menjalani coaching. Perubahan respon kemudian terjadi setelah masing-masing subjek menjalani pertemuan I. Pada pertemuan berikutnya, subjek lebih bersemangat untuk datang dan menanyakan jadwal selanjutnya. Saat pertemuan, subjek juga nampak antusias menjelaskan kondisi yang dialaminya dan lebih terbuka. Fasilitator bahkan mampu melakukan konfrontasi dengan subjek $Z$ yang terlihat sangat memegang teguh apa yang diyakininya. Menurut fasilitator, hal tersebut dapat dilakukannya karena subjek sudah percaya kepadanya. 


\section{Diskusi}

\section{A. Kemampuan Mengelola Emosi}

Pendampingan emosi (emotional coaching) yang diberikan terbukti mampı meningkatkan kemampuan mengelola emosi karyawan dalam menjalani perubahar organisasi. Hal tersebut dapat dilihat dalam grafik berikut.

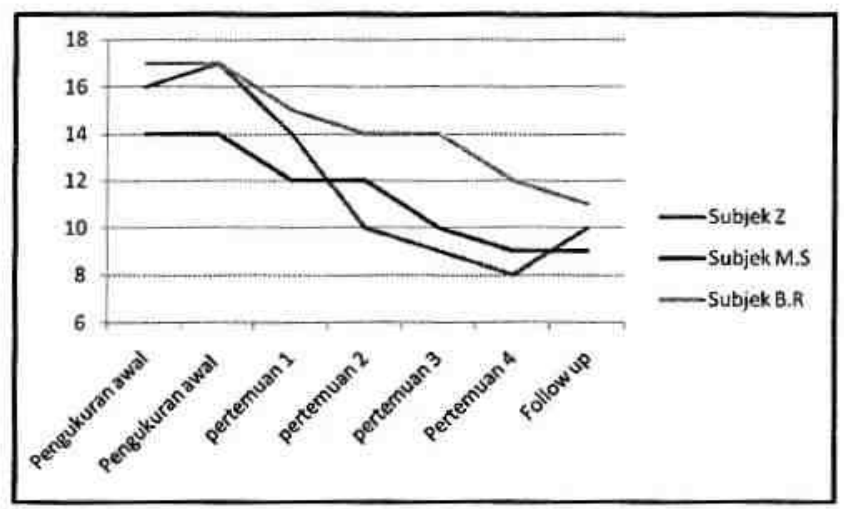

Gambar 6. Dinamika Skor Reaksi Emosional Subjek Penelitian

Gambar 6 menunjukkan bahwa reaksi emosional subjek secara umum mengalami penurunan. Hal ini mengindikasikan bahwa subjek telah memiliki kemampuan mengelola emosi. Secara umum selama proses coaching subjek mampu mengikuti materi yang diberikan karena merasakan adanya perubahan cara pandang terhadap situasi yang terjadi. Selain itu subjek juga merasa bahwa pengetahuan tambahan mengenai emosi dan bagaimana cara mengelolanya. Subjek menyadari bahwa dirinya sudah pernah mengalami apa yang disampaikan tetapi tidak memahaminya secara teoritis.

Berdasarkan hasil analisis terhadap proses coaching yang dilakukan kepada subjek terlihat bahwa pada awalnya masing-masing subjek merasakan adanya emosi-emosi negatif terkait dengan perubahan organisasi yang dialami. Emosi negatif tersebut di antaranya adalah tidak puas, kecewa, marah, jengkel, dan iri hati. Emosi negatif memunculkan berbagai sikap yang kemudian berubah menjadi perilaku. Menurut Kupers (2001), emosi merupakan faktor dinamis yang melatarbelakangi tindakan. Secara sadar, emosi akan dimanifestasikan dalam bentuk pengalaman emosi yang akan membentuk persepsi seseorang dalam memandang sesuatu. Oleh karenanya penerimaan seseorang terhadap sesuatu yang terjadi akan berbeda-beda dan dengan berbagai cara yang unik.

Penerimaan yang berbeda-beda dapat terlihat dari berbagai respon yang terkait dengan perubahan organisasi yang dialami masing-masing subjek. Subjek $\mathrm{Z}$ mengalami 
penurunan reaksi emosional yang sangat signifikan. Perubahan organisasi yang dialami oleh subjek membuatnya tidak mampu bekerja secara maksimal karena terkait dengan ketidakpuasan yang dirasakannya. Subjek kemudian bekerja secara "ogah-ogahan" dengan maksud agar diperhatikan oleh atasannya, karena pada dasarnya subjek adalah orang yang kurang mampu mengkomunikasikan apa yang dirasakannya. Selama coaching subjek akhirnya mampu membedakan antara emosi dan pikiran-pikiran negatif yang menyertainya, sehingga ada keinginan untuk lepas dari asumsi-asumsi. Hal tersebut akan dilakukan dengan bersikap lebih terbuka kepada atasannya.

Penurunan skor reaksi emosional subjek M.S cukup signifikan. Pada dasarnya, subjek sedang berusaha untuk menekan emosi negatifnya. Subjek menekuni bisnis di luar kantor untuk mencari peluang kerja di tempat lain. Namun demikian di sisi lain, subjek juga berusaha menanggapi emosi negatifnya dengan lebih berpikir positif. Subjek tetap optimis bahwa keadaan akan berubah. Oleh karenanya subjek tetap berusaha untuk bekerja dengan sebaikbaiknya karena berharap hal tersebut dapat menjadi acuan untuk promosi. Kondisi seperti ini cukup efektif bagi subjek, dirinya berhasil mendapatkan promosi jabatan. Hal ini sesuai dengan hasil penelitian yang dilakukan oleh Gross (Manz, 2007) bahwa menahan reaksireaksi atas emosi kurang efektif untuk meringankan pengalaman emosional yang negatif dibandingkan jika seseorang menerapkan strategi-strategi untuk mengetahui dan mengatur emosi (seperti menilai kembali situasi yang sulit). Subjek berhasil menanggapi emosi negatifnya dengan lebih berpikir positif.

Subjek B.R juga mengalami penurunan yang cukup signifikan reaksi emosionalnya. Saat ini, subjek selalu berusaha untuk memikirkan kesesuaian antara tindakan dengan emosi yang dirasakannya. Oleh karenanya sebelum bertindak, subjek berusaha menyadari emosi yang dirasakannya dan memikirkan apakah tindakannya tepat atau tidak. Subjek juga tetap optimis dan menyimpan harapan-harapan baru terkait dengan perubahan organisasi yang dialaminya. Emosi pada awalnya akan mengevaluasi apakah sesuatu itu baik atau buruk bagi seseorang dan memberikan predisposisi tindakan yang mengekspresikan keinginan atau kebutuhan (Greenberg, 2002). Subjek telah berusaha melakukan penilaian terhadap emosi yang dirasakan, bahkan menyesuaikan antara emosi yang dirasakan dengan tindakan yang akan dilakukan.

\section{B. Resistensiterhadap Perubahan}

Setelah mengikuti coaching ini maka secara umum terlihat adanya penurunan reaksi emosional terhadap perubahan. Subjek telah menerima dan menyesuaikan diri dengan 
perubahan, memiliki alternatif-alternatif pemecahan, dan punya tujuan baru yang lebih maju $\mathrm{Hal}$ ini kemudian mengindikasikan adanya penurunan resistensi terhadap perubahan. $\mathrm{He}$ tersebut dapat dilihat dengan menurunnya skor resistensi terhadap perubahan yang dicapa oleh masing-masing subjek penelitian. Skor tersebut diperoleh dengan menggunakan ala ukur Skala Resistensi terhadap Perubahan (Oreg, 2003). Setiap subjek penelitian mengalam penurunan skor resistensi terhadap perubahan mulai saat pengukuran awal hingga tindal lanjut

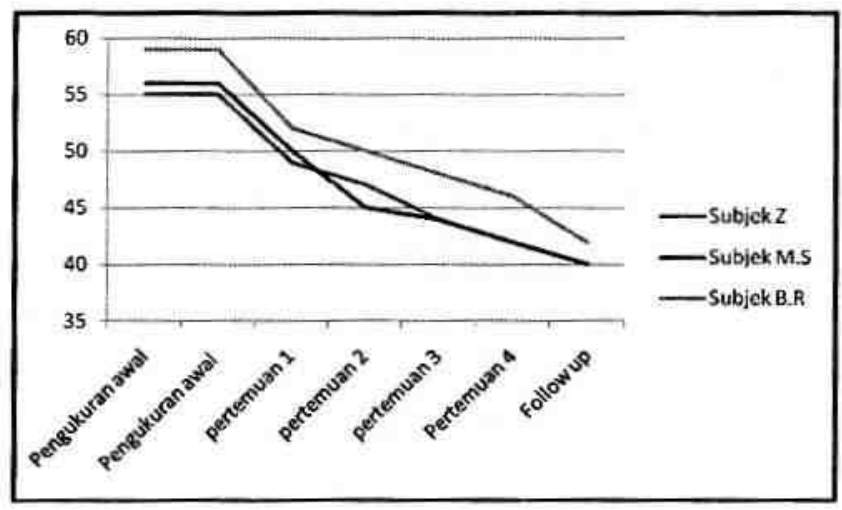

Gambar 7. Dinamika Skor Resistensi terhadap Perubahan Subjek Penelitian

Gambar 7 menunjukkan bahwa secara umum resistensi terhadap perubahan setiap subjek mengalami penurunan yang cukup signifikan. Berdasarkan hasil coaching terlihat bahwa pada awal perubahan organisasi setiap subjek menunjukkan adanya resistensi terhadap perubahan. Menurut Kreitner dan Kinicki (2003), resistensi terhadap perubahan adalah respon emosional/perilaku terhadap perubahan kerja yang nyata atau yang dibayangkan akan mengancam rutinitas kerja yang telah dibuat. Subjek Z mengalami penurunan resistensi terhadap perubahan yang cukup signifikan. Setelah perubahan organisasi, subjek mengalami situasi kerja yang sangat berbeda. Beban kerjanya makin meningkat, sementara atasan tidak memperhatikannya dan tidak mampu memotivasinya untuk bekerja dengan baik. Akibatnya, subjek bekerja secara "ogah-ogahan". Menurut Robbins (1994), ada beberapa alasan karyawan bersikap resisten, salah satunya adalah berubahnya kebiasaan. Karyawan cenderung memiliki aktivitas kerja yang rutin. Namun ketika terjadi perubahan organisasi, aktivitas yang menjadi kebiasaan tersebut ikut berubah dan cenderung menimbulkan ketidaknyamanan bagi karyawan. Selain itu, karyawan juga dapat bersikap resisten terhadap perubahan karena tidak adanya kepercayaan dalam situasi kerja. Seorang manajer yang membangun hubungan kerja dengan bawahannya atas dasar 
ketidakpercayaan akan memungkinkan menghadapi sikap resisten dari bawahannya ketika menggulirkan perubahan organisasi. Sementara seorang manajer yang mempercayai bawahannya, akan menilai perubahan sebagai hal yang sifatnya terbuka, jujur, dan partisipatif. Hal ini disebabkan adanya kepercayaan/ketidakpercayaan dalam hubungan kerja yang bersifat timbal balik (Robbins, 1994).

Subjek $\mathbf{Z}$ juga merasa penghasilan yang didapatkan belum sesuai dengan beban kerjanya. Menurut Robbins (1994), alasan lain karyawan bersikap resisten adalah faktor ekonomi. Penghasilan yang berkurang, kenaikan gaji yang tidak sesuai dengan harapan, serta meningkatnya harga kebutuhan pokok merupakan faktor ekonomi yang dapat menjadi pemicu bagi individu untuk bersikap resisten terhadap perubahan. Bila perubahan memiliki dampak ekonomi yang cukup besar terhadap individu, maka dapat diramalkan bahwa sikap resisten terhadap perubahan akan semakin kuat. Emotional coaching yang diberikan mampu membuat mengubah pandangan subjek mengenai perubahan dan pekerjaan yang sedang dijalani. Subjek juga ingin berusaha menghilangkan asumsi-asumsi mengenai atasannya dan akan mengkomunikasikan apa yang dirasakannya.

Secara umum, subjek M.S mengalami penurunan resistensi terhadap perubahan yang sangat siginifikan. Subjek awalnya merasakan ketidakpuasan dan tidak nyaman dengan perubahan. Gaji tidak sesuai dengan beban kerja, karena menurutnya golongannya salah. Oleh karenanya subjek kemudian memilih untuk menekuni bisnis lain di luar kantor. Menurut Palmer, Dunford, dan Akin (2006), alasan individu bersikap resisten terhadap perubahan antara lain merasa tidak nyaman dengan perubahan dan merasakan efek negatif yang berhubungan dengan kepentingannya. Selama coaching, subjek akhimya mampu bersikap optimis bahwa suatu saat keadaan berubah sehingga berusaha bekerja sebaik-baiknya.

Subjek B.R mengalami penurunan resistensi terhadap perubahan yang cukup signifikan. Pada awal coaching, merasa tidak nyaman dengan perubahan karena belum konsistennya pihak manajemen dalam menjalankan perubahan. Oleh karenanya subjek sebagai orang yang menangani HRD terkadang bingung dalam menerapkan aturan. Hal tersebut juga diperparah dengan ketidakmampuan subjek untuk bersikap tegas terhadap rekan kerjanya. Selama coaching subjek menemukan harapan baru terkait dengan perubahan yang dialami dan menyadari bahwa sebagai staf HRD maka hal tersebut harus dilakukannya terlebih dahulu.

Secara umum, sikap yang diperlihatkan oleh masing-masing subjek lebih menunjukkan resistensi pasif dari pada resistensi aktif. Menurut Palmer, Dunford, dan Akin (2006), salah satu simtom yang diidentifikasi sebagai resistensi pasif adalah kegagalan dalam 
mengimplementasikan perubahan. Hasil coaching memperlihatkan bahwa tidak ada subje yang cenderung menunjukkan resistensi aktif. Menurut Palmer, Dunford, dan Akin (2006) simpton yang diidentifikasi sebagai resistensi aktif diantaranya adalah mengintimidasi menghalangi, menyebarkan rumor, atau mengubah fakta mengenai perubahan.

Pendampingan emosi (emotional coaching) mampu dijalani dengan baik oleh masing masing subjek. Hal tersebut sangat dipengaruhi oleh keberhasilan fasilitator dalan menjalankan program. Fasilitator mampu membuat subjek mempercayainya yang akhirnya mendorong keterbukaan subjek menceritakan apa yang dirasakannya. Meskipun pade awalnya dengan alasan pekerjaan yang menumpuk, subjek enggan untuk mengikuti program, namun peneliti dan fasilitator mampu meyakinkannya untuk mengikuti program. Peneliti menyadarkan pentingnya program dengan menceritakan kondisi subjek berdasarkan hasil pengukuran awal dan pertimbangan dari pihak manajemen. Saat awal pertemuan, fasilitator mampu membuat subjek merasa nyaman dan percaya dengan hasil yang akan dicapai. Oleh karenanya tercipta kerja sama yang baik antara fasilitator dan subjek. Subjek merasa bersemangat untuk hadir di setiap pertemuan dan mengikuti coaching hingga akhir sesi. Keberhasilan program ini terlihat dari adanya kemampuan mengelola emosi oleh masingmasing subjek. Hal tersebut tergambar dari adanya keinginan subjek untuk menerima dan menyesuaikan diri dengan perubahan, adanya alternatif-alternatif pemecahan, dan harapan/tujuan baru yang lebih maju.

Kelemahan-kelemahan yang menjadi keterbatasan penelitian ini adalah: (1) Tidak adanya observer yang ikut dalam dalam pertemuan. Fasilitator sekaligus bertindak sebagai observer; (2) Subjek yang menjalani intervensi adalah karyawan yang tergolong resistensi pasif, sehingga efektivitas coaching belum teruji untuk karyawan yang tergolong aktif resisten; (3) Pengukuran setelah coaching (follow up) hanya dilakukan sekali saja; (4) Penelitian ini merupakan Small and Design sehingga hasil penelitian tidak dapat digeneralisasikan secara lebih luas; (5) Tidak adanya kelompok kontrol sebagai kelompok pembanding, sehingga hasil penelitian tidak dapat dibandingkan dengan kelompok yang tidak mendapat perlakuan.

\section{Simpulan dan Saran}

\section{Simpulan}

1. Pendampingan emosi (emotional coaching) terbukti mampu meningkatkan kemampuan mengelola emosi karyawan dalam menjalani perubahan organisasi.

2. Karyawan yang mampu mengelola emosi dalam menghadapi perubahan organisasi akan menurunkan tingkat resistensinya terhadap perubahan. 
3. Keberhasilan coaching sangat dipengaruhi oleh kemampuan fasilitator dalam menjalankan program. Fasilitator mampu membangun rapport dengan subjek sehingga menumbuhkan kepercayaan serta keterbukaan.

4. Keaktifan dan keterbukaan subjek dalam menjalani coaching membuatnya mampu menemukan sendiri solusi atas permasalahan yang dihadapinya.

\section{Saran}

Beberapa hal yang perlu disempurnakan agar pendampingan emosi (emotional coaching) dalam penelitian selanjutnya dapat memberikan hasil yang lebih optimal adalah:

1. Perlu adanya observer lain sebagai pembanding (inter rater).

2. Penelitian ini perlu dilakukan lebih lanjut pada subjek yang tergolong pasif resisten, sehingga efektivitas coaching dapat lebih teruji .

3. Pengukuran setelah coaching diberikan (follow up) perlu dilakukan lebih dari sekali untuk melihat konsistensi dari keberhasilan program.

4. Subjek penelitian perlu ditambah agar hasil penelitian dapat digeneralisasikan secara lebih luas.

5. Perlu adanya kelompok kontrol sebagai kelompok pembanding, sehingga hasil penelitian dapat dibandingkan dengan kelompok yang tidak mendapat perlakuan.

\section{Daftar Pustaka}

Barlow, D.H. \& Hersen,M. 1984. Single Case Experimental Designs: Strategies for Studying Behavior Change. Second Edition. NewYork: PergamonPress.

Bosowa Excellence Magazine. (22 Maret 2007). Bosowa Grup to be Bosowa Corporation. Hal 6-10.

Cote, S. \& Morgan, L. M. 2002. A Longitudinal analysis of the association between emotion regulation, job satisfaction, and intentions to quit. Journal of Organizational Behavior, $23,947-962$.

Cummnigs, T. G. \& Worley, C. G. 2005. Organizational development and change. $8^{\text {th }}$ Edition. Ohio: Thomson South Western.

Greenberg, L. S. 2002. Emotion-Focused Therapy. Coaching clients to work through their feelings. Washington:American Psychological Association.

Himam, F. 2005. Absorbing the wave of change: A Grounded case study in explaining change behavior in organization. Jurnal Psikologi, 32(1), 13-23. 
Hutri, M. \& Lindeman, M. 2002. The role of stress and negative emotions in an occupatione crisis. Journal of Career Development, 29(1), 19-36.

Huy, Q. N. \& Insead 1999. Emotional capability, emotional intelligence, and radical change The Academy of Management Review, 24(2), 325-345.

Jones, G. R. 2004. Organizational theory, design, and change. Singapore: Pearson Education Inc.

Jordan, P. J., Ashkanasy, N. M., Hartel, C. E. J. 2002. Emotional intelligence as a moderatoro emotional and behavioral reactions to job insecurity. Academy of Managemen Review, 27(3), 361-372.

Kiefer, T. 2005. Feeling bad: Antecedents and consequences of negative emotions in ongoins change. Journal of Organizational Behavior, 26(8). 875

Küpers, W. 2001. A phenomenology of embodied passion and the demotivational realities o organization. Paper. To be presented at CMS 2001, Manchester at the Stream.

Kreitner, R \& Kinicki, A. 2003. Organizational behavior. New Jersey: Prentice Hall, Inc.

Lupton, D. 1998. The Emotional self. London: Sage Publications.

Manz, C. C. 2007. Manajemen emosi. Yogyakarta: Think.

Mayer, J. D. \& Salovey, P. 1997. What is emotional intelligence, (http://www.unh.edu/emotional intelligence, diakses 20 April 2008).

Muzdalifah. 2007. Efektivitas pelatihan kesadaran emosi terhadap peningkatan kreativitas. Tesis. Tidak diterbitkan. Yogyakarta: Universitas Gadjah Mada.

Nur, H. 2007. Memahami pengalaman emosi bagi karyawan dalam menghadapi perubahan organisasi. Suatu pendekatan fenomenologi. Tesis. Tidak diterbitkan. Yogyakarta: Universitas Gadjah Mada.

Oreg, S. 2003. Resistance to change: Developing an individual differences measures. Journal of Applied Psychology, 88(4), 680-692.

Palmer, I., Dunford, R., Akin, G. 2006. Managing Organizational Change. A Multiple Perspectives Approach. New York: Mc Graw Hill Companies.

Robbins, S.P. 1994. Essential of Organizational Behavior. Fourth Edition. London: PrenticeHall International, Inc (UK) Limited.

Smitter, R. D., Houston, J. M., \& McIntire, S.A. 1996. Organization development: Strategies for changing environment. New York: Harper Collins College Publisher.

Somers, M. 2007. Coaching at work. Powering your team with awareness, responsibility and trust. England: Jossey-Bass AWiley Imprint.

Strongman, K. T. 2003. The psychology of emotion: from everyday life to theory. England: John Wiley \& Sons Ltd. 
Weber, P. S. \& Weber, J. E. 2001. Changes in employee perceptions during organizational change. Leadership \& Organizational Developmental Journal, 22(1), 291-300.

Yeyentimalla 2007. Efektivitas pelatihan kecerdasan emosi terhadap peningkatan komunikasi terapeutik mahasiswa keperawatan-pasien (di Akper Pemda Kapuas Kalimantan Tengah). Tesis. Tidak diterbitkan. Yogyakarta: Universitas Gadjah Mada. 